\title{
Flexural strength and modulus of elasticity of different types of resin-based composites
}

\author{
Resistência à flexão e módulo de elasticidade \\ de diferentes tipos de resina composta
}

\author{
Sinval Adalberto Rodrigues Junior ${ }^{(a)}$ \\ Cesar Henrique Zanchi(b) \\ Rodrigo Varella de Carvalho(a) \\ Flávio Fernando Demarco(c)
}

(a) PhD Students; (b)MSc Student; (c)PhD, Professor - Department of Restorative Dentistry, School of Dentistry, Federal University of Pelotas.

\author{
Corresponding author: \\ Flávio Fernando Demarco \\ Faculdade de Odontologia - UFPel \\ Rua Gonçalves Chaves, 457 \\ Pelotas - RS - Brazil \\ CEP: 96015-560 \\ E-mail:fdemarco@ufpel.edu.br
}

Received for publication on Apr 04, 2006 Sent for alterations on Jun 21, 2006

Accepted for publication on Aug 02, 2006

\begin{abstract}
The aim of the study was to test whether the filler composition of resin composites influences their flexural strength and modulus of elasticity. Flexural strength and modulus of elasticity were obtained through a three-point bending test. Twelve bar shaped specimens of 5 commercially available composites - Supreme (3M/ESPE), a universal nanofilled composite; Esthet-X (Dentsply), Z-250 (3M/ESPE), Charisma (Heraeus Kulzer), universal hybrid composites; and Helio Fill (Vigodent), a microfine composite - were confectioned according to the ISO 4049/2000 specifications. The test was performed after a 7days storage time using a universal test machine with a crosshead speed of $1 \mathrm{~mm} / \mathrm{min}$. The filler weight content was determined by the ashing technique. The data obtained on the mechanical properties were submitted to ANOVA and Tukey test $(\mathrm{p}<0.05)$. Pearson's correlation test was used to determine the correlation between the filler content and the mechanical properties. A weak but significant correlation between the mechanical properties evaluated and the filler weight content was observed $(\mathrm{p}<0.000)$. The microfine composite presented the lowest filler weight and the lowest mechanical properties. Statistically different flexural strength and modulus of elasticity results were observed among the universal hybrid composites. The nanofilled composite presented intermediary results. Within the limitations of this in vitro study, it could be concluded that the filler content significantly interfered in the flexural strength and modulus of elasticity of the composites tested.
\end{abstract}

Descriptors: Composite resins; Physical and chemical properties; Inorganic particles.

Resumo: O objetivo do presente estudo foi avaliar se o conteúdo inorgânico exerce influência na resistência à flexão e no módulo de elasticidade de compósitos restauradores. Para determinar a resistência à flexão e o módulo de elasticidade foi realizado o teste de resistência à flexão por três pontos. Doze espécimes em formato de barra de cinco compósitos disponíveis comercialmente - Supreme (3M/ESPE), compósito universal nanoparticulado; Esthet-X (Dentsply), Z-250 (3M/ESPE), Charisma (Heraeus Kulzer), compósitos universais híbridos; e Helio Fill (Vigodent), compósito microparticulado - foram confeccionados conforme as especificações da ISO 4049/2000. Após 7 dias de armazenagem em água o teste foi realizado em uma máquina de ensaio universal com velocidade de carga de $1 \mathrm{~mm} / \mathrm{min}$. A avaliação do peso do conteúdo inorgânico foi determinada através da incineração da fase orgânica. Os dados obtidos referentes às propriedades mecânicas foram então submetidos à Análise de Variância e ao teste Tukey $(\mathrm{p}<0,05)$. Para se determinar a correlação entre o conteúdo inorgânico e as propriedades mecânicas foi realizado o teste de correlação de Pearson. Uma fraca, porém significante correlação entre as propriedades mecânicas avaliadas e o peso do conteúdo inorgânico foi observada $(\mathrm{p}<0,000)$. O compósito microparticulado apresentou menor conteúdo inorgânico e propriedades mecânicas mais baixas. Também foram observados valores de resistência à flexão e módulo de elasticidade estatisticamente diferentes entre os compósitos híbridos. O compósito nanoparticulado apresentou valores intermediários. Dentro das limitações deste estudo in vitro, pode-se concluir que o conteúdo inorgânico interfere significantemente na resistência à flexão e no módulo de elasticidade dos compósitos testados.

Descritores: Resinas compostas; Propriedades físicas e químicas; Partículas inorgânicas. 


\section{Introduction}

Since the introduction of dental resin-based composites as posterior restorative materials, their clinical behavior has been dictated by their mechanical properties. During the " 70 s and ' 80 s the main reasons of failure of composite restorations were insufficient wear resistance, loss of anatomic form and proximal contacts, and degradation of the restoration. ${ }^{10}$ The improvement in filler technology resulted in more resistant composites and changed the reasons of failure and restoration replacement. ${ }^{12}$ As the composites improved their wear resistance through the incorporation of filler, they also became more brittle materials, increasing the prevalence of bulk fractures.

Resin-based composites mechanical properties are mainly dependent upon their microstructure and composition. The microstructural characteristics involve the distribution of filler particles in the bulk, the morphology of these filler particles and the presence of pre-existing cracks and voids. These characteristics are directly related to the composition of the composite.

Asmussen, Peutzfeldt ${ }^{2}$ (1998) observed that the variation of the BisGMA/TEGDMA/UEDMA ratio affected significantly the mechanical properties of the composite, suggesting that specific combinations should be developed according to the specific applications of the material. The long-term durability, evaluated by means of water sorption and solubility of the composites, has also been shown as depending on their organic content. ${ }^{17}$ However, the inorganic filler content is to be considered the most valuable factor concerning the improvement of the mechanical properties of resin-based composites ${ }^{3}$ and, thus, it has been largely studied.

Kim et al. ${ }^{9}$ (2002) observed a significant influence of the filler rate and morphology on the flexural strength and modulus, microhardness and fracture toughness of the composites evaluated. Also, Yap, Teoh ${ }^{18}$ (2003), comparing different categories of composites, observed that the microfine composite, with the lowest filler content ( $40 \%$ in volume), presented the lowest flexural properties (strength and modulus).

Other factors besides the filler content, such as degree of conversion and type of monomer, could also influence the mechanical behavior of composites. ${ }^{1,6}$ In fact, the morphological aspect of the filler determines its percentage, the silane content and the microstructural characteristics of the composite. ${ }^{15}$

The incorporation of nanometric sized filler particles in hybrid composites and even the introduction of exclusively nanofilled composites have been considered the most recent advances in filler technology. Characteristically, these filler particles, due to their considerably small size and rounded shape, expose a high surface area and require, as a consequence, a higher amount of silane. Musanje, Ferracane ${ }^{13}$ (2004) found that the incorporation of silanized nanofiller particles significantly increased abrasion and attrition wear resistance of an experimental hybrid composite.

Flexural strength is a meaningful mechanical property for brittle materials, although the results cannot be extrapolated to the clinical behavior without considering some aspects, namely flaw distribution $^{11}$ and structural reliability of the material. ${ }^{5}$ Nonetheless, the in vitro three-point bending flexural test is recommended by the ISO $4049 / 2000^{8}$ specification for polymer-based materials and is widely used for comparative purposes. ${ }^{4,14}$

Another important mechanical parameter provided by the flexural test is the modulus of elasticity, which describes the rigidity of the material. Different clinical situations demand resin-based restorative materials with different moduli of elasticity. Class V (cervical) cavities, for example, demand a low modulus restorative material to flex with the tooth. A relatively high modulus, on the other hand, is expected from posterior composites to withstand the occlusal forces and preserve the adhesive interface.

Several authors have reported a significant correlation between the modulus of elasticity and the percentage of filler by volume $(\mathrm{vol} \%)^{3,7}$ or by weight (wt\%). ${ }^{16}$ Sabbagh et al. ${ }^{16}$ (2002), evaluating the modulus of elasticity of several resin-based composites commercially available observed significantly different moduli, even for composites of the same category, indicating that compositional differences between composites from different manufacturers (the kind of monomer, the shape and size of the inorganic filler) influence the mechanical behavior of the materials. 
The purpose of the present study was to assess the filler composition effect in different commercially available resin-based composites, concerning flexural strength and modulus of elasticity.

\section{Material and Methods Filler weight}

To determine the filler weight content, the weight $\left(\mathrm{W}_{0}\right)$ of an increment of each composite resin was measured in an analytical balance (AG200, Gehaka, São Paulo, SP, Brazil). The increments were heated at $900^{\circ} \mathrm{C}$ for 30 minutes in an electric furnace to eliminate the organic matrix including all the carbon remnants. After that, they were re-weighed $\left(\mathrm{W}_{1}\right)$. The weight of the filler fraction was determined using the following formula:

$$
\mathrm{Wt} \%=\left(\mathrm{W}_{1} / \mathrm{W}_{0} \times 100 \%\right)
$$

\section{Flexural strength and elasticity modulus}

Twelve bar shaped specimens were made of each composite (Table 1), using a metallic mold with the dimensions specified by the ISO 4049/2000 specification ( $25 \mathrm{~mm} \times 2 \mathrm{~mm} \times 2 \mathrm{~mm}$ ).

The mold was positioned over a glass slide and a mylar strip and filled with the composite, which was inserted in a single increment. Another mylar strip was positioned and pressed against it with a glass slide for excess removal before polymerization. A light-curing unit with $450 \mathrm{~mW} / \mathrm{cm}^{2}$ (Ultralux, Dabi Atlante, Ribeirão Preto, SP, Brazil) and a $10 \mathrm{~mm}$ light guide were used. Its light intensity was measured with a radiometer Model 100 (Demetron Research Corp., Danbury, CT, USA) before use. The composite was cured for 40 seconds in three consecutive points, producing a partial overlapping. The excess of material in the corner was carefully removed with a scalpel blade and the specimens were stored in distilled water at room temperature for 7 days. Afterwards, they were submitted to a threepoint bend test with a universal testing machine (4411, Instron, Barueri, SP, Brazil) with a crosshead speed of $1 \mathrm{~mm} / \mathrm{min}$. The maximum loads were obtained and the flexural strength $(\sigma)$ was calculated in megaPascals (MPa) by using the following formula:

$$
\sigma=3 F L /\left(2 B H^{2}\right)
$$

where $\mathrm{F}$ is the maximum load (in newtons); $\mathrm{L}$ is the distance between the supports (in millimeters); B is the width of the specimen (in millimeters) and $\mathrm{H}$, the height (also in millimeters).

The modulus of elasticity $(\mathrm{GPa})$ was determined as:

$$
\mathrm{E}=\mathrm{FL}^{3} / 4 \mathrm{BH}^{3} \mathrm{~d}
$$

where $\mathrm{F}$ is the maximum load; $\mathrm{L}$ is the distance

\begin{tabular}{|c|c|c|c|c|c|c|}
\hline Composite & Manufacturer & Classification & Organic Matrix & Filler & Shade & Batch no. \\
\hline Supreme (SU) & 3M/ESPE & $\begin{array}{l}\text { Nanofilled } \\
\text { Univ RBC }\end{array}$ & $\begin{array}{l}\text { BIS-GMA, BIS- } \\
\text { EMA, UDMA and } \\
\text { TEGDMA }\end{array}$ & $\begin{array}{l}78.5 \% \text { in weight (clusters of } \\
0.6 \text { to } 1.4 \mu \text { - particules of } 5 \\
\text { to } 20 \mathrm{~nm})-\mathrm{Zr} \text { and } \mathrm{Si}\end{array}$ & $\mathrm{B} 2 \mathrm{E} ; \mathrm{C} 3 \mathrm{~B}$ & $\begin{array}{l}2 A G \\
2 A B\end{array}$ \\
\hline Esthet-X (EX) & Dentsply & $\begin{array}{l}\text { Hybrid } \\
\text { Univ RBC }\end{array}$ & $\begin{array}{l}\text { BIS-GMA and } \\
\text { TEGDMA }\end{array}$ & $\begin{array}{l}60 \% \text { in volume; } 77 \% \text { in weight } \\
\text { ( } 0.6 \text { to } 0.8 \mu \text { and } 0.02 \text { to } \\
2.5 \mu \text { - glass powder (BAFG); } \\
10 \text { to } 20 \mathrm{~nm} \text { - silica dioxide) }\end{array}$ & A2; A3.5 & $\begin{array}{l}0106283 ; \\
0105302\end{array}$ \\
\hline Z-250 (Z2) & $3 M / E S P E$ & $\begin{array}{l}\text { Hybrid } \\
\text { Univ RBC }\end{array}$ & $\begin{array}{l}\text { BIS-GMA, UDMA } \\
\text { and BIS-EMA }\end{array}$ & $\begin{array}{l}60 \% \text { in volume (average of } \\
0.19 \text { to } 3.3 \mu)-Z r \text { and } \mathrm{Si}\end{array}$ & A2 & $2 U E$ \\
\hline Charisma $(\mathrm{CH})$ & Heraeus Kulzer & $\begin{array}{l}\text { Hybrid } \\
\text { Univ RBC }\end{array}$ & BIS-GMA & $\begin{array}{l}64 \% \text { in volume }(\mathrm{Ba} \text { and } \\
\text { Al glass }-0.02-2 \mu \text {; silica } \\
\text { dioxide }-0.02-0.07 \mu)\end{array}$ & C3 & 020027 \\
\hline Helio Fill (HF) & Vigodent & Microfine RBC & & Silica dioxide & $\begin{array}{l}\mathrm{A} 1 \mathrm{E} ; \\
\mathrm{A} 2 \mathrm{E}\end{array}$ & $\begin{array}{l}11002 ; \\
11502\end{array}$ \\
\hline
\end{tabular}
between the supports; $\mathrm{B}$ is the width of the speci-

Table 1 - Information about the composites employed according to the manufacturers.

$\mathrm{RBC}=$ Resin-based composite; Univ = Universal; BAFG = Barium aluminofluorosilicate glass. 
men, $\mathrm{H}$ is the height of the specimen, and $\mathrm{d}$ is the deflexion (in millimeters) corresponding to the load F.

The fractured specimens were analyzed with a stereoscopic lupe $(40 \mathrm{X})$ to observe the fracture pattern.

\section{Statistical analysis}

The data obtained from the tests were submitted to ANOVA and Tukey test $(\mathrm{p}<0.05)$. Pearson's correlation test was used to establish if there was any correlation between the filler $\mathrm{wt} \%$ data and the mechanical properties.

\section{Results}

The statistical analysis pointed out significant differences between composites both for the flexural strength and the modulus of elasticity (Table 2).

The highest flexural strength was obtained with $\mathrm{Z} 2$ and it was followed by EX. SU and CH had similar behaviors and presented higher flexural strengths than the microfine composite HF.

The modulus of elasticity of EX was similar to that of Z2 and significantly higher than that of the other composites. Similar moduli were observed between $\mathrm{Z} 2$ and $\mathrm{SU}$ and between $\mathrm{CH}$ and HF.

A significant positive correlation $(\mathrm{p}<0.000)$ was found between the filler weight and the mechanical properties flexural strength $(\mathrm{r}=0.591)$ (Graph $1 \mathrm{~A})$ and modulus of elasticity $(r=0.423)$ (Graph 1B).

All the fractures initiated in the traction surface of the specimens, between the inner support points. All the fractured specimens generated two pieces, except for one EX specimen, that generated three.

\section{Discussion}

The three-point bending test is based on the International Organization for Standardization (ISO) specification n. 4049/2000 for polymer-based restoratives and is widely employed in dental research. ${ }^{4,14,18}$ The flexural bending test, classified as opening mode test or Mode I, is usually recommended because the specimen fabrication and the load application are quite simple. ${ }^{11}$ Although some studies have suggested alternative flexural test designs, ${ }^{4,18}$ the three-point bending test is still the

Table 2 - Flexural strength, elasticity modulus and weight of filler content for each composite.

\begin{tabular}{c|c|c|c}
\hline Composite & Flexural Strength $(\mathrm{MPa})$ & Elasticity modulus $(\mathrm{GPa})$ & Filler in weight (\%) \\
\hline $\mathrm{SU}$ & $119.43( \pm 18.68) \mathrm{C}$ & $5.76( \pm 1.49) \mathrm{B}$ & 84 \\
\hline $\mathrm{EX}$ & $145.67( \pm 13.96) \mathrm{B}$ & $6.93( \pm 0.69) \mathrm{A}$ & 79 \\
\hline $\mathrm{Z} 2$ & $168.87( \pm 15.36) \mathrm{A}$ & $6.40( \pm 0.96) \mathrm{AB}$ & 74 \\
\hline $\mathrm{CH}$ & $127.39 \pm \pm 11.77) \mathrm{C}$ & $5.28( \pm 0.73) \mathrm{C}$ & 64 \\
\hline $\mathrm{HF}$ & $86.32( \pm 8.82) \mathrm{D}$ & $4.95( \pm 0.70) \mathrm{C}$ & 1.11 \\
\hline Tukey value $(5 \%)$ & 16.34 & & \\
\hline
\end{tabular}

Standard deviation is represented in parentheses; Different letters represent significantly different values.
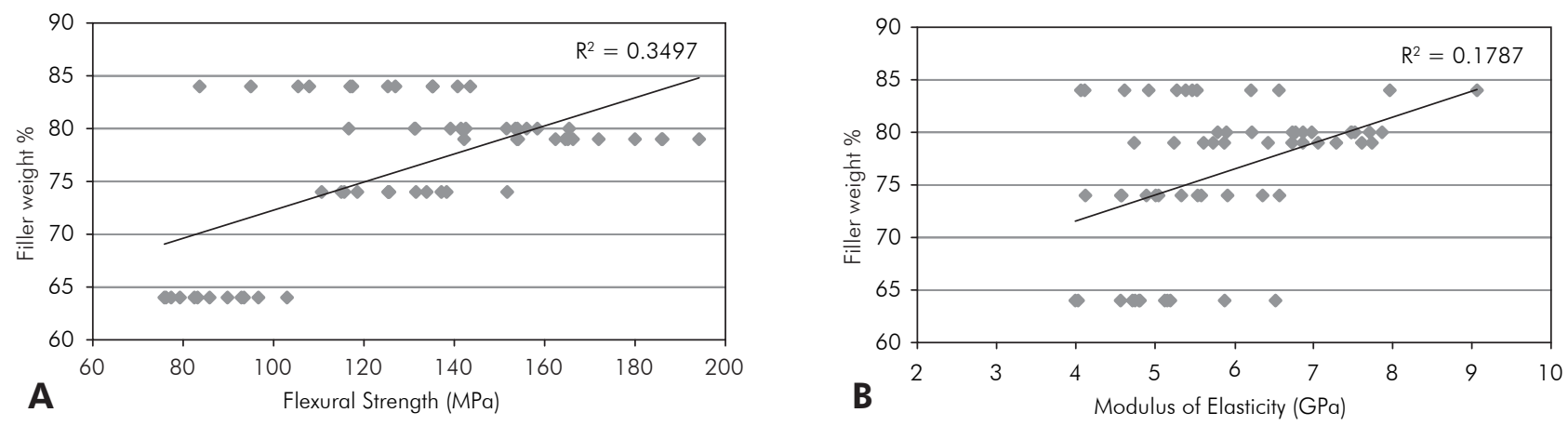

Graph 1 - Association between filler weight and flexural strength (A); Association between filler weight and modulus of elasticity (B). 
choice for evaluating composites flexural strength due to the lower standard deviation, the lower coefficient of variation and the less complex crack distribution produced by it when compared to those produced by other test designs, such as the biaxial flexural test. ${ }^{4}$

Fracture is one of the major reasons for clinical failure of dental composite restorations. ${ }^{12}$ The fracture of brittle materials, such as composites, occurs through the propagation of pre-existing cracks under tensile stress. These cracks may be produced by bubble incorporation during insertion of the material, polishing or may appear due to microstructural imperfections. ${ }^{5}$ According to Loughran et al. ${ }^{11}$ (2005), crack initiation is strongly affected by the microstructural characteristics of the material that may cause stress concentrations, surface scratches, microcracks etc.

The present study associated both the mechanical properties analyzed with the filler content percentage in weight $(\mathrm{wt} \%)$. Although studies usually associate the mechanical behavior of composites to their filler vol $\%,{ }^{3,7}$ this parameter is more complex to obtain, since it involves the previous determination of the filler density, taking into account the variation of the filler morphology and the molecular composition. Furthermore, Ferracane et al. ${ }^{6}$ (1985) found a strong correlation between the filler wt $\%$ and vol $\%$, having chosen only one of them to correlate with the mechanical properties of the composites studied.

The filler wt $\%$ obtained by the ashing technique for some of the composites evaluated (SU and EX) differed from that reported by the manufacturers' specifications, according to previous studies. ${ }^{9,15}$ Not all the manufacturers provided the information about the filler wt $\%$ fraction of their composites.

The comparison between the composites from the same category (hybrid universal resin-based composites) showed a statistically significant difference in flexural strength and modulus of elasticity, even with a low variation of filler wt $\%$. Also, a correlation between the highest filler wt $\%$ and the highest mechanical properties evaluated was not observed, indicating that other factors than the filler $\mathrm{wt} \%$ are involved in the mechanical behavior of the composites studied. ${ }^{1}$
The morphological characteristics of the fillers must also be considered, since they have been shown to be determining factors in both the filler loading ${ }^{1,3,9,15}$ and the material strength. ${ }^{1,9}$ Smooth spherical shaped filler particles are related to an increased volume fraction of the filler due to the improved packing of the particles and also to higher fracture strength. This could explain the high flexural strength and modulus obtained with Z2, which is constituted by small round shaped particles. ${ }^{15}$ Furthermore, rounded particles tend to distribute more uniformly the mechanical stress than irregular shaped particles that present sharp angles, already known as stress concentration areas from where the cracks may start. ${ }^{15} \mathrm{~A}$ morphological characterization of the filler content of $\mathrm{CH}$ and EX showed particles of varying size and shape and greater spaces between particles when compared to that of $\mathrm{Z} 2 .{ }^{15} \mathrm{EX}$ is also constituted by silanized nanometric filler particles, which have been pointed as capable of increasing the flexural strength and the microhardness of composites. ${ }^{13}$

As expected, the microfine composite presented the lowest filler $\mathrm{wt} \%$ and the lowest mechanical properties. Kim et al. ${ }^{9}$ (2002), who established a classification for composites based on the filler morphological characteristics, observed that the presence of pre-polymerized filler particles was associated to low filler content and to low mechanical properties. Microfine composite resins (indicated for anterior restorations), such as HF, usually present in their composition these pre-polymerized particles. Indeed, these composites have a silica filler loading (0.04 $\mu \mathrm{m}$ average size) embedded in an organic matrix, resulting in $10-50 \mu \mathrm{m}$ sized blocks of filler. ${ }^{15}$ The size and the shape of the particles may justify the low filler loading in this composite category.

The nanofilled composite presented intermediate flexural strength and modulus of elasticity results. This composite is constituted exclusively by silanized nanometric sized silica particles $(20 \mathrm{~nm})$ and clusters of Si/Zr. Small filler particles expose a higher surface area to be coated by silane, making the silanization process more critical ${ }^{15}$ and increasing the chances of an interfacial failure. A comparison between SU and Z2, from the same manufacturer, disclosed superior values of flexural strength for $\mathrm{Z} 2$ but 
similar values of modulus of elasticity, which may have been influenced by the organic matrix content. The presence of TEGDMA in the composite matrix composition has been associated to a significant decrease in the flexural strength of the material, while, paradoxically, it has also been associated to an increase in the modulus of elasticity. ${ }^{2}$ The characteristic flexibility of TEGDMA allows the creation of a dense and flexible polymer network ${ }^{17}$ that increases the composite elastic deformation. However, in the present study, composites presenting TEGDMA in their composition also showed significantly different

\section{References}

1. Adabo GL, Cruz CAS, Fonseca RG, Vaz LG. The volumetric fraction of inorganic particles and the flexural strength of composites for posterior teeth. J Dent. 2003;31(5):353-9.

2. Asmussen E, Peutzfeldt A. Influence of UEDMA, BisGMA and TEGDMA on selected mechanical properties of experimental resin composites. Dent Mater. 1998;14(1):51-6.

3. Braem M, Lambrechts P, Van Doren V, Vanherle G. The impact of composite structure on its elastic response. J Dent Res. 1986;65(5):648-53.

4. Chung SM, Yap AUJ, Chandra SP, Lim CT. Flexural strength of dental composite restoratives: comparison of biaxial and three-point bending test. J Biomed Mater Res B Appl Biomater. 2004;71(2):278-83.

5. Della Bona A, Anusavice KJ, DeHoff PH. Weibull analysis and flexural strength of hot-pressed core and veneered ceramic structures. Dent Mater. 2003;19(7):662-9.

6. Ferracane JL, Matsumoto H, Okabe T. Time-dependent deformation of composite resins - Compositional considerations. J Dent Res. 1985;64(11):1332-6.

7. Ikejima I, Nomoto R, McCabe JF. Shear punch strength and flexural strength of model composites with varying filler volume fraction, particle size and silanation. Dent Mater. 2003;19(3):206-11.

8. International Organization for Standardization. ISO 4049/2000 - Dentistry - Polymer-based filling, restorative and luting materials. Switzerland: ISO; 2000.

9. Kim KH, Ong JL, Okuno O. The effect of filler loading and morphology on the mechanical properties of contemporary composites. J Prosthet Dent. 2002;87(6):642-9. flexural strength and modulus of elasticity values indicating that, as already stated, the mechanical properties result from a complex combination of microstructural and compositional factors that vary in the manufacturing process and that cannot be considered in an isolated way. ${ }^{1,2}$

\section{Conclusions}

Within the limitations of this in vitro study, it could be concluded that the filler content significantly interfered in the flexural strength and modulus of elasticity of the composites.

10. Leinfelder KF, Sluder TB, Santos JFF, Wall JT. Five-year clinical evaluation of anterior and posterior restorations of composite resins. Oper Dent. 1980;5:57-65.

11. Loughran GM, Versluis A, Douglas WH. Evaluation of subcritical fatigue crack propagation in a restorative composite. Dent Mater. 2005;21(3):252-61.

12. Manhart J, Chen HY, Hamm G, Hickel R. Review of the clinical survival of direct and indirect restorations in posterior teeth of the permanent dentition. Oper Dent. 2004;29(5):481508.

13. Musanje L, Ferracane JL. Effects of resin formulation and nanofiller surface treatment on the properties of experimental hybrid resin composite. Biomater. 2004;25(18):4065-71.

14. Palin WM, Fleming GJ, Marquis PM. The reliability of standardized flexure strength testing procedures for a light-activated resin-based composite. Dent Mater. 2005;21(10):9119.

15. Sabbagh J, Ryelandt L, Bachérius L, Biebuyck JJ, Vreven J, Lambrechts $\mathrm{P}$, et al. Characterization of the inorganic fraction of resin composites. J Oral Rehabil. 2004;31(11):1090-101.

16. Sabbagh J, Vreven J, Leloup G. Dynamic and static moduli of elasticity of resin-based materials. Dent Mater. 2002;18(1):6471.

17. Sideridou I, Tserki V, Papanastasiou G. Study of water sorption, solubility and modulus of elasticity of light-cured dimethacrylate-based dental resins. Biomater. 2003;24(4):65565.

18. Yap AUJ, Teoh SH. Comparison of flexural properties of composite restoratives using the ISO and mini-flexural tests. J Oral Rehabil. 2003;30(2):171-7. 